\title{
Locally Advanced Cervical Adenocarcinoma
}

National Cancer Institute

\section{Source}

National Cancer Institute. Locally Advanced Cervical Adenocarcinoma. NCI Thesaurus.

Code C156297.

A cervical adenocarcinoma that has spread from its original site of growth to nearby tissues or lymph nodes. 